\title{
CASE REPORT: UNCONTROLLED HYPERTENSION CONTRIBUTES TO WORSENING OF PRESBYCUS SYMPTOMS IN THE ELDERLY
}

\section{Faradila Budi Saputri', Azizah Amimathul Firdha', Safira Rahma ${ }^{1}$, Rieza Rizqy Alda ${ }^{1}$, Syahwina Inayasari ${ }^{1}$, Nyilo Purnami*2 ${ }^{10}$}

${ }^{1}$ Faculty of Medicine, Universitas Airlangga, ${ }^{2}$ Department of Ear Nose Throat (ENT)-Head and Neck Surgery, Faculty of Medicine, Universitas Airlangga-RSUD Dr. Soetomo Surabaya

\begin{abstract}
Presbycusis is a disease that can befall the elderly, caused by a multifactorial process that should be allowed to disrupt communication and social life and cause mental disorders. According to $\mathrm{WHO}$ the proportion of the elderly population rises rapidly which is estimated in 2025, there will be about 1,2 billion elderly people with a risk of presbycusis. Mr. S was 84 years old, married, and had 2 children, complained of hearing loss since 10 years ago on the patient's left ear. The decline in hearing occurred gradually, giving the last 4 years after his wife's death. The patient was taken to Otorhinolaryngologist and expressed age-related hearing impairment and was advised to use hearing aids. The patient was not routinely using hearing aids. Besides, patients have hypertension and heart disease. Patient consumed Captopril 2x1 tablets, Fundifar 2x1, Furosemide 1x40 $\mathrm{mg}$ and Fargoxin $1 \times 0.25 \mathrm{mg}$. Patients do not routinely consume cardiac medicine and used hearing aids. From the results of heteroanamnesis, physical examination, and audiogram examination conducted in Mr. S patients, it can be concluded that Mr. S suffers from presbycusis with hypertensive and congestive heart failure. Mr. S was advised to routinely have their hearing check to Otorhinolaryngologist as an evaluation and routine control to Cardiologist.
\end{abstract}

\section{ARTICLE HISTORY}

Received: January 19, 2020

Revised: May 2, 2020

Accepted: June 2, 2020

Published: June 30, 2020

(Online)

doi: 10.20473/jemphr.v1i1.20298

\section{KEYWORDS}

Presbycusis; Hearing loss, Elderly, Hypertension, Congestive Heart

Failure

\section{CORRESPONDING AUTHOR}

Nyilo Purnami

$\triangle$ nyilo@fk.unair.ac.id

Department of Ear Nose Throat (ENT)-Head and Neck Surgery, Faculty of Medicine, Universitas Airlangga-RSUD Dr. Soetomo

Surabaya, Jl. Mayjen

Prof. Dr. Moestopo No. 6-8, Airlangga, Gubeng Surabaya, Indonesia

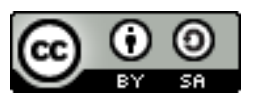

\section{INTRODUCTION}

Presbycusis is a disease that can afflict the elderly due to multifactorial processes that can cause varying degrees of severity. If presbycusis is allowed to disrupt communication and social life will be disrupted and cause mental disorders. ${ }^{1}$ In the United States, the prevalence of hearing loss is directly proportional to an increase in age of about $43 \%$. Hearing loss is found at ages over 65 years.

Presbycusis is a sensorineural disorder caused by the aging process. Degenerative processes occur in Corti organ cells and nerve fibers that play a role in the hearing 
process. Symptoms that arise in the form of deafness that is progressive and slow that can be accompanied by tinnitus or ears often buzzing without cause. Deafness caused by presbycusis is usually bilateral and symmetrical, generally affecting the perception of the high and low tones received by the hearing instrument 3 . The symptoms of presbycusis can cause balance disorders so that the patient has a great risk of falling4. The many symptoms that cause disability and communication problems cause patients to have problems of self-confidence, depression, and stress that have a major impact on their quality of life. ${ }^{5}$

Presbycusis is not completely treatable, but presbycusis can be prevented and relieve symptoms such as the use of hearing aids, surgery, and the use of pharmacological drugs. In the future, it is not unlikely that stem cell methods will be found which will be a powerful method in treating presbycusis. ${ }^{6}$

\section{CASE REPORT}

Mr. S, 84 years old, married and has 2 children, complained of hearing loss 10 years ago in the patient's left ear. Hearing loss occurs gradually, weighing the last 4 years after the death of his wife. Never felt ears buzzing but there was no headache. There is no history of trauma. No history of work and living in a noisy place. Complaints of decline are also complained of by family and neighbors of patients because when communicating with others patients often ask back questions raised by others by looking at the mouth of the speaker. The patient's family and neighbors must also raise their voices when communicating with patients less than 1 meter apart. Because hearing loss is getting heavier, the family brings it to the ENT-Head Neck specialist at Dr. Iskak Tulungagung on November 7, 2017

The patient was checked for hearing, the patient was asked to hear a sound at a certain distance and asked for clarity of hearing in each ear in a special room. Then the doctor stated to the family that if the patient's hearing loss complaint is likely due to age and the doctor advised the family to buy a hearing aid patient and the patient uses it. These tools can be purchased at Dr. Iskak and enough to buy hearing aids for the left ear only at a price of 3 million Rupiah. After using a hearing aid, patients can hear sounds clearly. Patients can easily adjust the volume on the hearing aid according to convenience, starting from the lowest level and the corresponding volume 2 of volumes 1-4 available on the device. However, the last few months, patients do not routinely use it because it is not convenient if they use it every day because hearing aids are complained of frequent release. The family has persuaded to routinely use hearing aids but failed. Patients do not routinely control to the ENT-Head Neck doctor to have their hearing checked.

The patient has had high blood pressure since 2007 and heart disease since 1 month 
ago, with complaints of shortness of breath, to have to be seated every time he sleeps, looks panting every time he walks, urinates a little, and swells in both legs. Patients taking Captopril $2 \times 1$ tablets, Fundifar $2 \times 1$, Furosemide 1 x $40 \mathrm{mg}$ and Fargoxin (Digoxin) 11 x $\quad 0.25 \quad \mathrm{mg}$. Complaints of shortness of breath and swelling of the feet in the patient improved, so that the second child as a caregiver patient stopped heart treatment without doctor's advice. Patients only regularly consume Captopril and Fundifar. Patients do not routinely go to the doctor for high blood pressure and heart problems because there are no complaints.

In the family, the patient's first child has a hearing loss but is missing and has hypertension. The patient has a history of smoking since young and has stopped since the age of 50 years. The patient's appetite is good with a frequency of eating 3 times a day. Patients regularly walk around the house at least 3 times a week. Patients can still do their daily activities independently except for bathing, patients are assisted by their children. The patient's house is generally quite clean, well ventilated and well-lit. The patient's home is in a complex that is not close to the noise.

On physical examination found breath frequency 20 times per minute, pulse 88 times per minute, temperature 36.8 degrees, blood pressure 140/100 $\mathrm{mmHg}$. Physical examination of the head, neck, thorax, abdomen, and extremities within normal limits. Audiometry examination was carried out on November 7, 2017 when the patient was 81 years old at the Iskak Tulungagung Regional Hospital. From this audiometry test the results were ADD 56-25 db and ADS 68-25 db. With the conclusion of the Medium Dextra Sensorineural Deaf Audiogram and Severe Sinistra Sensorineural Deafness in the patient.

From these data the patient was diagnosed with presbycusis with accompanying diagnoses of hypertension and congestive heart failure. The medical therapy plan is given captopril $25 \mathrm{mg}$ twice daily, furosemide $40 \mathrm{mg}$ once daily, digoxin 0.25 mg once daily, multivitamin 2 times a day 1 capsule. For non-medical therapy, patients are advised to routinely use hearing aids, avoid stress, not smoke and avoid cigarette smoke, a low-fat diet, maintain a healthy lifestyle, avoid noisy places, avoid consuming drugs other than doctor's advice, routine control for heart disease and hypertension. In addition, patients are advised to consult a heart specialist regarding heart disease and to the ENT-Head Neck doctor for an evaluation of the patient's hearing. The patient's family is advised when communicating with patients, they should get closer and speak clearly and the volume is turned up. In addition, the family also must routinely remind patients to use assistive devices, take medicine, and keep the patient's food so that it is low in fat. 


\section{DISCUSSION}

In this case the results obtained heteroanamnesis with the main complaint of Hearing Loss. Hearing loss in these patients occurs in both ears especially more severe in the left ear. This incident occurred 10 years ago when the patient was 75 years old, and increasingly heavier when 3-4 years ago, when his wife died. Symptoms of hearing loss in this patient are: do not respond when called, the patient asks the interlocutor to raise their voice when communicating, the patient asks the interlocutor to repeat the question while communicating, and often there is discrimination in speech tones ie the patient cannot understand the contents of the conversation when someone is communicating with patients. From this incident the patient's family brought the patient to check the symptoms. The patient was taken to the ENT-Head Neck specialist Iskak Tulungagung Hospital.

A person can be said to have a hearing loss with symptoms: not responding when called, raising the volume when talking, turning up the sound Television or Radio. ${ }^{7}$

This is in accordance with complaints experienced by patients so that it can be concluded that the patient has a hearing loss. From the data obtained, this patient is 65 years old. This age stepped on the elderly. The age limit is: Middle age is the age group of 45 to 59 years, the elderly (elderly) age between 60 to 74 years, old age (old) age between 75 to 90 years, very old age (very old) age over 90 years (WHO).

In old age this will occur an aging process that occurs physiologically which develops continuously and affects the anatomical, physiological, and biochemical processes in the body so that it will affect the decline in all bodily functions8. In the Elderly there will be changes in body function, one of which is the loss of the ability of hearing in the inner ear, especially to the sounds of sounds or high notes, unclear sounds, difficult to understand words $50 \%$ occur at ages over the age of 65 years, tympanic membrane atrophy causes muscle secretion, cerumen collection can harden due to increased keratin. Hearing decreases in elderly people who experience mental stress or stress. ${ }^{9}$

In this patient, the elderly is 84 years old so that degenerative occurs in organs in the body including hearing organs. From the results of literature and complaints, this incident is in accordance with the experience of patients with decreased hearing function due to aging of the degenerative process.

From heteroanamnesis history of the patient's disease, the patient also experienced a concomitant disease that is chronic hypertension. The patient's blood pressure is $140 / 100$ according to JNC VIII division, which is Stage 1 Hypertension. Hypertension is a non-communicable disease which is a "silent killer" meaning that if the disease occurs continuously, it 
will be dangerous for patients. ${ }^{8}$ Definition Hypertension is a state of increased systolic blood pressure of more than 140 $\mathrm{mmHg}$ and diastolic more than equal to 90 mmHg. ${ }^{11}$ Therefore it can be seen in this patient also has hypertension which is a non-communicable and chronic disease. So that this chronic disease that causes several other disease complications.

Prolonged hypertension can aggravate vascular resistance which results in endothelial cell dysfunction in blood vessels. The pathogenesis of the circulatory system can occur in blood vessels in the inner ear accompanied by increased blood viscosity, decreased capillary blood flow and oxygen transport. As a result, there is damage to auditory cells, and the signal transmission process that can cause hearing loss which will result in communication disorders. ${ }^{12}$ So it appears in patients who begin to appear symptoms of hearing loss is also associated with hypertension that affects patients. From these results the basis for patients receiving hypertension drug treatment is Captopril which aims to control the patient's blood pressure. So that it can reduce the risk of other disease complications. And so as not to aggravate hearing loss in patients. However, patients do not take hypertension medication regularly, so that the patient's blood pressure is not controlled which results in complaints of hearing loss. Patients have difficulty communicating.
In the next stage will be able to aggravate complaints of hearing loss in patients. From here the patient will also experience social disorders because they feel unable to adapt to social and unacceptable to the community. Resulting in the patient will be detached from society, feel alienated, depressed, and lonely. The role of the family is very important in this case to deal with patient complaints. What the family can do for patients is to speak clearly and slowly. Do not shout, talk to the patient in a bright room, avoid talking in a place with a background of crowds and noise. ${ }^{7}$

From the supporting examination, a hearing test is performed on the patient, the test is the Audiometry test. This test is carried out on November 7, 2017, when the patient is 81 years old. From this audiometry test, the results were ADD $56.25 \mathrm{db} /$ ADS $68.75 \mathrm{db}$. From audiometry tests conducted at Iskak Tulungagung Regional Hospital by ENT specialists, on the results of the Audiogram came the description of Severe Dextra/Sinistra Sensorineural Deafness in the patient. Several tests can be done to determine the type and severity of hearing loss experienced by someone. The test is also influenced by age.

Some of these tests according to WHO 2020 include: Otoacoustic emissions (OAE) or auditory brainstem response (AABR) tests that can be performed on infants and children up to the age of five. These tests are often done using a 
handheld device when they are sleeping. They are fast and easy to do. When a child fails this test repeatedly (twice), he will be sent for an auditory brain stem response test. The second is auditory brainstem response tests: these tests are usually only available in specialized centers. This test is often done after calming the baby. Next is the Pure Tone Audiometry test: children older than five years and adults can have their hearing examined with a simple test, using pure tone audiometry (PTA). In this test, sounds from different tones are presented to each ear and the person is asked to respond when he can hear it.

The Hearing Level in humans is in normal people the sound that can be heard is $<20 \mathrm{~dB}$, at the level of $20-<35 \mathrm{db}$ ie mild hearing loss means that someone may be difficult to hear what is said in a noisy place. At $35-<50 \mathrm{db}$ is moderate hearing loss meaning that people may have difficulty hearing conversations, especially in noisy places. At the level of 50- $<65 \mathrm{db}$ moderately severe hearing loss, that is, someone has difficulty hearing some parts of the conversation, but can still hear the conversation louder than normal voice. At the level of $65-<80 \mathrm{db}$ which is severe hearing loss means not hearing most of the conversation and difficulty hearing voices and extreme difficulty hearing in extreme places and participating in communication. At the level of profound hearing loss is 80$<95 \mathrm{db}$ which means it is very difficult to hear voices. And the most severe level is complete hearing loss/deafness reaching $95 \mathrm{db}$ or more meaning it cannot hear at all the conversation in various sound and environmental conditions. ${ }^{7}$

In this patient the audiometry results described moderate to severe deafness. In the right ear $56.28 \mathrm{db}$ and in the left ear which has a slight severe deafness from the right. From this basis, ENT specialists recommend the use of "hearing aid" in patients for both ears. But since this "hearing aid" is expensive and is not covered by the BPJS, the patient only buys 1 "hearing aid" for the left ear, which experiences more severity than the right. After using this hearing aid the patient's hearing starts to improve. Symptoms of hearing loss as mentioned above have started to decrease.

From Heteroanamnesis obtained data on symptoms of hearing loss in levels, advanced patient age, and there are risk factors for hypertension, as well as audiometric results that show patients experiencing moderate moderate deafness in the right ear and left ear. This is the basis that patients experience Presbycusis. The diagnosis of presbycusis is based on patient complaints in the form of symptoms in patients who show hearing loss and speech discrimination. There is a clinical picture of an audiogram explaining sensorineural hearing loss at high frequencies, occurring bilaterally and symmetrically of the right and left ear. This disorder starts in middle age to old age13. Presbycusis is a hearing loss of neural sensory type, in both ears especially at high frequencies. This incident occurs in 
older people starting in the 3rd or 4th decade and is clearly seen at 65 years to over 65 years. This hearing loss occurs degeneratively accompanied by discrimination of speech tones. ${ }^{13}$

This patient using hearing aids, so this tool can help patients when communicating with people. Patients use hearing aids from after the audiometry test in 2017. The hearing aids used by patients is by means of the patient can adjust the volume of the hearing aids until the patient feels comfortable. Patients feel comfortable using Hearing Aids in Volume 2 which does not have Desible magnitude information that can help reduce the hearing level on the patient's audiogram results. In Volume 2 the patient can hear better when not using a hearing aid. But the hearing aids used by patients are only the left one. This is related to the cost of purchasing "Hearing aid" which is expensive and not covered by BPJS. Also, in this patient's case ABD is rarely used. There is no control from the family to the patient to use hearing aids. So that sometimes in everyday patients still can not communicate well with people around. In addition, when patients use hearing aids can help patients in hearing, but complaints of discrimination in speech tones persist, that is, cannot understand the purpose of a conversation. Hearing aids can improve hearing ability for elderly patients who have decreased hearing. Aiming that the patient is still able to communicate. However, in patients who experience speech discrimination, when speaking in a noisy environment they can still have difficulty hearing even though they are using Hearing Aids. This is because the disorder occurs at the level of perception rather than on receiving the stimulus ${ }^{14}$.

After 3 years from the initial use of "Hearing Aid" in the patient no further evaluation is carried out to improve the patient's condition, the Family never takes the patient to the hospital again for evaluation after the use of "Hearing aid". Evaluation is only done by looking at the patient's clinical course. When an independent test is done by calling the patient, the family must speak closer to the patient's ear and speak in a voice that is louder than usual. Even from 1 meter the patient cannot hear the sound well. Just can hear well at a distance of approximately $20 \mathrm{~cm}$.

Management that can be done in presbycusis patients is by way of prevention into the incidence of presbycusis that is getting more severe. Because presbycusis itself healing is difficult. Prevention includes avoiding noise while communicating, low-fat diets, avoiding cigarettes and alcohol, avoiding stress. The main problem encountered in Presbycusis patients is communication disorders. The purpose of this treatment is to help patients communicate well. Because basically this Presbycusis cannot be helped with surgery or drugs. What can be done is to use Hearing Aids (ABD) to greatly help sufferers in hearing 
impairment. However, although this ABD can help sufferers of presbycusis in hearing, it still cannot restore hearing to normal. ${ }^{13}$ To overcome the hearing loss in patients, rehabilitation can also be done including reading exercises (Speech reading), listening exercises (auditory training). And family attention is needed to pay more attention to patients. Routine to see a doctor if there is a deterioration in the condition of hearing in patients such as discharge from the patient's ear ${ }^{15}$.

\section{CONCLUSION}

From heteroanamnesis and physical examination as well as secondary data of the patient Mr. At the age of 84 we diagnosed Presbycusis patients with accompanying diagnoses of hypertension and congestive heart failure. In patients experiencing elderly namely 75 years and over degenerative organs in the body including the hearing organ. Because basically Presbycusis is not a disease, but a physiological process of body tissue due to aging in the hearing organ. The main problem encountered in Presbycusis patients is communication disorders. Presbycusis cannot be helped with surgery or medication, which can be done is to use a hearing aid (ABD) or hearing aid, this tool will help the hearing but does not return to normal. Things that can help in dealing with decreased hearing function in presbycusis are reading exercises (Speech reading), listening exercises (auditory training). This treatment is done to help patients to be able to communicate well, so they do not feel ostracized. Mr. S supports the treatment of patients by always accompanying therapy and control to the doctor and reminding patients to take medication and use hearing aid. In addition, patients are also advised to always live a healthy life, take medication regularly, control stress and maintain diet and then must routinely control for heart disease and hypertension to the Cardiologist.

\section{REFERENCES}

1. Gates GA, Mills JH. Presbycusis. Lancet. 2005 Sep 2430;366(9491):1111-20.

2. Nash SD, Cruickshanks KJ, Head Neckein R, et al. The prevalence of hearing impairment and associated risk factors: The Beaver Dam Offspring Study. Arch Otolaryngol Head Neck Surg. 2011 May;137(5):432-9.

3. Maqbool M, Mahbool S, Textbook of Ear, Nose and Throat Diseases. 11th ed. New Delhi; Jaypee Bro Med; 2007, 120 p.

4. Lin FR, Metter EJ, O'Brien RJ, Resnick SM, Zonderman AB, Ferrucci L. Hearing loss and incident dementia. Arch Neurol. 2011;68(2):214-220.

5. Arlinger S. Negative consequences of uncorrected hearing loss--a review. Int J Audiol. 2003;42 Suppl 2:2S17-2S20.

6. Hussain B, Qasim M, Masoud M, Khan L. Hearing impairments, 
presbycusis and the possible therapeutic interventions. Biomed Res Ther. 2017 Apr 20;4(4):122845.

7. WHO. Geneva: Basic ear and hearing care resource. 2020. Access: May 19, 2020

8. Depkes dan Kesos RI. Pedoman kemitraan lintas sektor dalam pembinaan lanjut usia. 2001. Jakarta: Departemen Kesehatan.

9. Maryam, SR, et al. Mengenal Usia Lanjut dan Perawatannya. 2008. Jakarta:Salemba Medika

10. Ekowati R, Sulistyowati T. Prevalensi hipertensi dan determinannya di Indonesia. Majalah Kedokteran Indonesia. 2009; 59(12).

11. Kuswardhani RAT. Penatalaksanaan hipertensi pada lanjut usia. Jurnal Penyakit Dalam. 2006; 7(2):135-40.

12. Tobian L. Salt and hypertension. Lessons from animal models that relate to human hypertension. Hypertension. 1991 Jan 1;17(1): $52-$ 8

13. Yusuf, Muhtarum et al. Pedoman praktis Head Neckinis telinga hidung tenggorok bedah kepala dan leher. Dept-Smf Ilmu Kesehatan Tht-Head Neck Rsud Dr. Soetomo FK Universitas Airlangga Surabaya. 2016. Surabaya

14. Roland, Peter S. presbycusis. Sited from

http://emedicine.medscape.com/artic le/855989-overview\#a0104 Januari 2013-01-13

15. Dhingra, P L and Deeksha, Diseases of Ear, Nose \& Throat. $6^{\text {th }}$ ed. New Delhi; Elsevier. 2014. 37p 